\title{
Pariwisata Dan Pelestarian Warisan Budaya
}

\section{Siswanto}

Keywords: cultural resource management, tourism, utilization, heritage, conservation

\section{How to Cite:}

Siswanto, nfn. (2007). Pariwisata Dan Pelestarian Warisan Budaya. Berkala Arkeologi, 27(1), 118-130. https://doi.org/10.30883/jba.v27i1.946

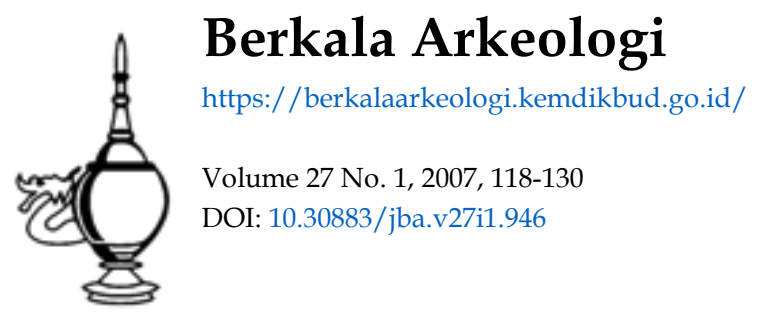

\section{c) (1) (5)}

This work is licensed under a Creative Commons Attribution-NonCommercial-ShareAlike 4.0 International License. 


\title{
PARIWISATA DAN PELESTARIAN WARISAN BUDAYA
}

\author{
Siswanto \\ (Balai Arkeologi Yogyakarta)
}

\section{Pendahuluan}

"Di seluruh dunia peninggalan sejarah dan pariwisata mempunyai hubungan yang tidak terpisahkan. Pariwisata digunakan sebagai alasan ekonomi untuk pelestarian warisan juga membantu pelestarian benda-benda artefak dan kehidupan rakyat di mata wisatawan" (Hewison dalam Hall. 1999).

Paradigma pembangunan di banyak negara kini lebih berorientasi kepada pengembangan sektor jasa dan industri, termasuk di dalamnya adalah industri pariwisata. Demikian juga halnya di Indonesia dalam tiga dasawarsa terakhir sektor pariwisata telah didorong dan ditanggapi secara positif oleh pemerintah dengan harapan dapat menggantikan sektor minyak dan gas (migas) yang selama ini menjadi primadona dalam penerimaan devisa negara. Sektor pariwisata memang cukup menjanjikan untuk turut membantu menaikkan cadangan devisa dan secara pragmatis juga mampu meningkatkan pendapatan masyarakat. Situasi nasional yang kini mulai memperlihatkan perkembangan ke arah kestabilan khususnya dalam bidang politik dan keamanan akan memberikan jaminan kepercayaan kepada wisatawan asing untuk masuk ke wilayah Indonesia.

Waktu senggang atau leisure dan aktifitas pariwisata saat ini semakin menjadi bahan komoditi, dalam masyarakat kapitalis waktu senggang masyarakat dibentuk secara langsung dengan apa yang ditawarkan dalam bentuk "industri budaya". Demikian pula pariwisata budaya telah menjadi bahan komoditi yang dapat dikelola secara bisnis untuk meghasilkan devisa atau ekonomi-sentris, oleh karena itu efek atau dampak langsung adalah pada budaya dan karakter masyarakatnya.

Waktu senggang dengan berwisata budaya membuka peluang lebih jauh apabila wisatawan akan mendapatkan sesuatu atau oleh-oleh yang 
bermanfaat setelah mereka pulang ke rumah masing-masing berupa "ilmu" dari obyek wisatanya. Akan tetapi peluang tersebut saat ini rupanya masih jauh dimanfaatkan karena perlu diakui masih banyak masyarakat wisatawan yang memahami apa yang mereka lihat. Di masyarakat dalam berwisata terbagi dalam dua kondisi, pertama yaitu dari kesadaran penuh bahwa kami harus kesana untuk melihat apa dan akan kami peroleh apa, kedua masih memanfaatkan dengan setengah terpaksa dan mungkin terpaksa yang penting sudah sampai disana. Di sisi lain oleh karena rendahnya pemahaman terhadap benda-benda peninggalan sejarah dan purbakala maka wisatawan cenderung kurang memahami pula tentang kelestarian dan makna-makna kultural yang luhur tinggalan tersebut.

Kebudayaan dan harta peninggalan nenek moyang, seperti diwujudkan melalui seni dapat ditingkatkan atau diturunkan dengan adanya dampak dari pariwisata (Hughes, dalam Hall, 1999). Kata lain dampak pariwisata terhadap budaya maupun peninggalan budaya bisa berdampak positif dan bisa berdampak negatif. Peninggalan sejarah dan purbakala di Indonesia sejak lama dimanfaatkan sebagai obyek wisata walaupun belum secara keseluruhan dan difungsikan secara optimal. Akan tetapi seiring perjalanan waktu apa dampak yang timbul hingga sekarang?, dan bagaimana mengantisipasi dan atau mengatasi dampak?.

\section{Pariwisata Budaya dan Pelestarian Benda Cagar Budaya}

Pengertian pelestarian benda cagar budaya adalah salah satu rangkaian dalam pengelolaan benda cagar budaya disamping unsur penelitian, pemanfaatan dan pembinaan. Kegiatan pelestarian terkandung unsur perlindungan, pemugaran, pemeliharaan, pendokumentasian dan publikasi, sedangkan kegiatan pemanfaatan seperti dalam Undang-undang Benda Cagar Budaya No. 5 tahun 1992 salah satunya adalah pemanfaatan untuk pariwisata. 


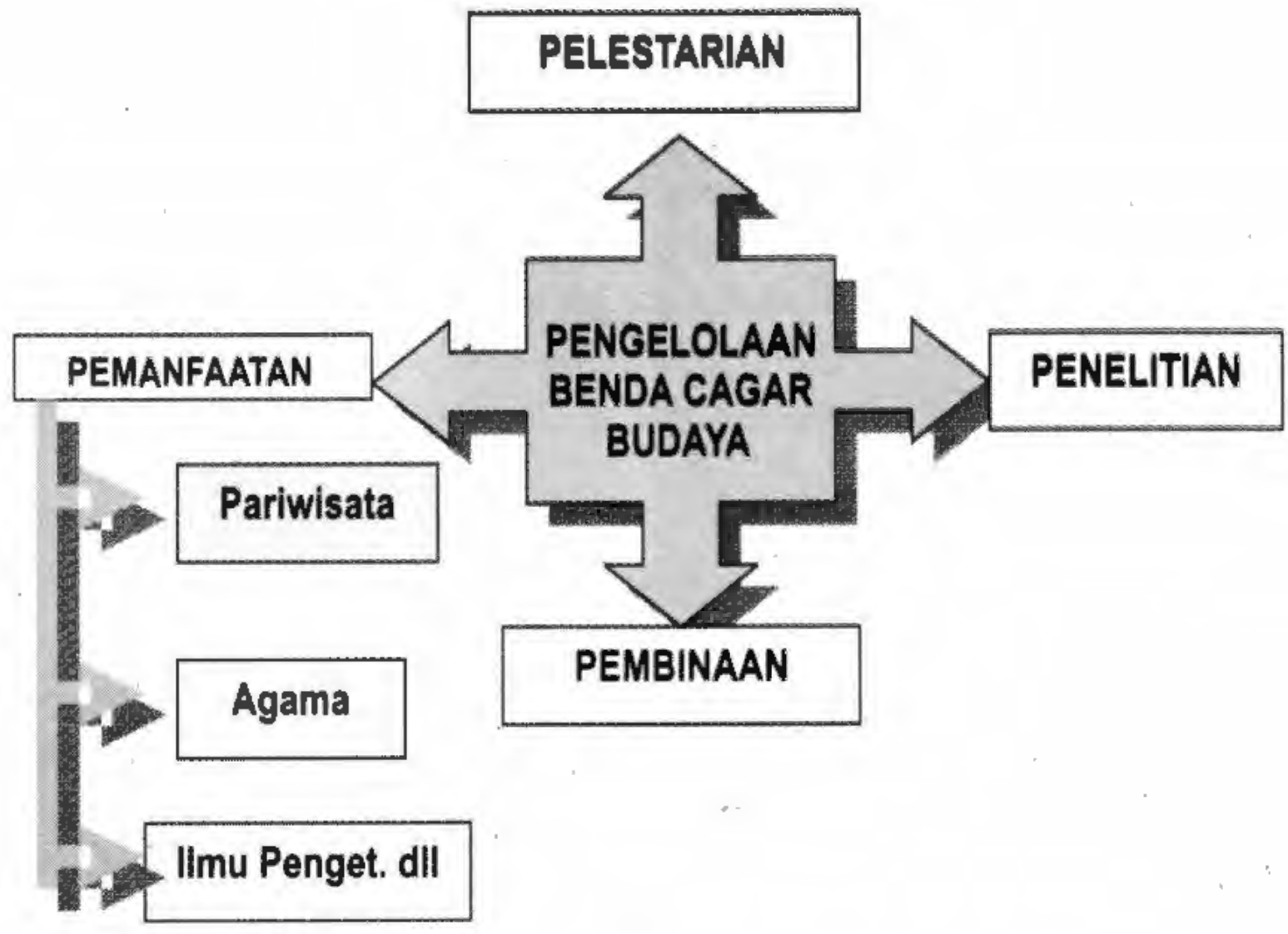

Diagram Alir Pengelolaan Benda Cagar Budaya

Pemanfaatan benda peninggalan sejarah dan purbakala untuk kegiatan pariwisata juga diatur dalam kode etik pariwisata dunia (Global Code of Ethics For Tourism) pada pasal 4 ayat 2 yang menyebutkan:

"Kebijakan kegiatan pariwisata harus diarahkan dalam rangka penghormatan terhadap warisan kekayaan seni, arkeologi dan budaya, yang harus dilindungi dan diserahkan kepada generasi penerus; pemeliharaan secara khusus diberikan guna pelestarian dan peningkatan monumen-monumen, tempat-tempat suci dan museum, demikian pula tempat-tempat bersejarah dan arkeologis, yang harus dibuka secara luas bagi kunjungan wisatawan umum harus didorong agar dapat masuk ke dalam kekayaan dan monumenmonumen budaya swasta (pribadi) dengan menghormati hak-hak pemiliknya, dèmikian pula ke dalam bangunan-bangunan keagaman, tanpa merugikan norma-norma agama" 
Pengembangan pariwisata budaya yang bersifat tangible (bendawi) adalah salah satu bentuk edukatif kultural yang bertujuan untuk mengenalkan kepada masyarakat tentang peninggalan sejarah purbakala untuk dapat dipahami dan akhirnya dapat dicintai. Melalui benda-benda peninggalan nenek moyang kita dapat belajar, memahami dan mengambil sisi positif tentang kehidupan masa lalu dan peradabannya untuk menata kehidupan masa kini dan menatap ke masa depan. Akan tetapi belum semua pemahaman ini melekat kepada seluruh lapisan masyarakat, pada umumnya yang terjadi wisatawan berwisata ke suatu tempat baru tahap ingin tahu, mengagumi keindahan dan keunikan obyek, kepuasan dan pengalaman hidup yang telah sukses mencapai obyek wisatanya saja atau dengan kata lain mereka pada umumnya masih dalam kemasan mencari "hiburan" dalam memanfaatkan waktu senggang atau "liburan" nya.

Kondisi mencari hiburan saat liburan ini implikasinya sejalan dengan perilaku mereka yang sering dijumpai pada obyek wisata adalah menjadi ancaman terhadap pelestarian benda cagar budaya. Kekaguman dan kecintaan direfleksikan dengan mengambil sebagain benda-benda purbakala untuk kenangan, kegembiraan dan kenangan diwujudkan dengan berpose di atas benda purbakala, kenangan untuk identitas dirinya diwujudkan dalam goresan namanya pada benda purbakala tidak hanya pada buku kunjungan, dan masih banyak contoh lain yang mengancam kelestarian, Pada akhirnya pada kondisi ini sangat disayangkan setelah mereka pulang ke rumah dari wisata budayanya mereka tidak memperoleh apa-apa untuk batinnya tentang benda peninggalan purbakala yang mereka lihat, yang mereka bawa pulang adalah hanya album photo dan benda-benda souvenir saja. Sehingga dengan demikian yang menjadi permasalahan pariwisata pada obyek peninggalan budaya adalah;

1. Benda budaya yang mereka kunjungi hanya sebagai "tempat" wisata saja.

2. Berwisata ke obyek benda budaya pada umumnya masih dalam kemasan mencari hiburan pada saat liburan.

3. Wisatawan pada umumnya sedikit memperoleh ilmu tentang obyek yang budaya yang dikunjungi. 
Minat masyarakat pariwisata budaya benda-benda purbakala saat masih dalam bentuk konsumsi memanjakan indera penglihatan, sehingga obyek wisata budaya yang menarik adalah bila secara fisik dan mengagumkan seperti candi-candi besar seperti Candi Borobudur, Candi Prambanan, dan lainnya. Museum dan tempat-tempat peninggalan sejarah dan purbakala lainnya masih menjadi pilihan selanjutnya. Di sisi lain rendahnya kesadaran masyarakat terhadap penghargaan pada benda-benda peninggalan sejarah dan purbakala mendorong tindakan-tindakan yang mengancam kelestarian, pemalsuan dan penipuan, pengangkatan dan perdagangan harta peninggalan secara ilegal, dan pencurian benda purbakala.

Di lain pihak walaupun secara tidak disengaja wisatawan yang berkunjung ke suatu obyek wisata peninggalan sejarah dan purbakala dengan jumlah terlampau padat lama kelamaan akan menjadi ancaman kelestarian, misalnya terjadi keausan pada obyek. Hal ini sangat dilematis apabila lokasi rawan aus misalnya pintu masuk dan tangga diganti dengan bahan lain dan yang asli disimpan. Satu kepentingan ingin mempertahankan keaslian supaya tidak membohongi publik sedangkan di pihak lain hal itu perlu dilakukan demi kelestarian. Tentunya hal bersifat teknis ini perlu kesepakatan dari berbagai pihak dengan menujukkan solusi terbaik.

\section{Pariwisata Budaya dan Perubahan Nilai}

Peranan pariwisata dalam hal perubahan nilai-nilai pribadi maupun kelompok tidak dapat dipisahkan dari pokok pikiran tentang "komoditisasi", yang menunjukkan bahwa apa yang dulunya merupakan "pertunjukan atau atraksi kebudayaan" perorangan maupun kelompok dari suatu tradisi kebudayaan hidup yang asli telah berubah menjadi "produk/hasil kebudayaan" untuk memenuhi kebutuhan komersil pariwisata, dengan kata lain kebudayaan telah menjadi suatu "komoditas" (Hall, 1999). Sebagai contoh kebudayaan suatu suku bangsa dalam bentuk perorangan maupun keragaman budaya dikemas kemudian dijual dengan menggunakan praktek-praktek bisnis profesional, melaui festival biasa maupun eventevent istimewa lainnya. Promosi dan pemasaran melalui festival-festival dari cara menghidupkan kembali budaya yang telah punah sebagai paket yang akan dijual ke wisatawan. Upaya menghidupkan kembali budaya tersebut menjadikan suku bangsa dan budayanya menjadi komoditas 
pariwisata. Praktek semacam ini banyak bermunculan di berbagai daerah di Indonesia baik skala lokal maupun regional.

Komoditas ini menjadi bernilai karena keuntungan devisa atau pendapatan suatu daerah yang diperoleh, akan tetapi nilai-nilai budayanya menjadi menurun karena yang ditonjolkan bentuk atraktifnya saja sedangkan "jiwa" dan apresiasinyá tidak ada lagi terutama yang dirasakan oleh pelaku. Contoh bentuk-bentuk seni seperti lukisan-lukisan Papunya Tula di Australia bagian tengah sekarang diproduksi dalam jumlah banyak untuk memenuhi permintaan wisatawan, hal ini mengarah pada penurunan kualitas, kesamaan dan pencemaran makna dalam dunia seni melalui perdagangan dan tidak adanya apresiasi terhadap kejadian-kejadian penting dari masa penciptaan suku Aborigin atau "dreamtime" (Hall, 1999). Lebih lanjut Hall menegaskan bahwa dengan adanya minat wisatawan dan dampak pasar yang ada, bahan-bahan, bentuk dan makna kesenian Aborigin disesuaikan dengan minat wisatawan asing. Meskipun demikian permintaan industri pariwisata yang begitu luas membuat upaya mengembalikan bentuk seni budaya tradisional suku Aborigin ke asalnya adalah sesuatu yang mustahil dan mungkin dari sudut pandang ekonomi tidak menguntungkan.

Perubahan nilai berkaitan dengan pariwisata tidak hanya terjadi melalui transformasi atifitas-aktifitas sosial ke produk, perkenalan tentang bentuk baru aktifitas ekonomi mungkin akan mempunyai dampak terhadap nilai kultur dan struktur tertentu. Meskipun demikian Hall mengatakan bahwa ciri mendasar dari industri pariwisata adalah dapat menimbulkan proses alkulturasi dan perubahan nilai yang khusus pada pariwisata. Lebih lanjut mencontohkan bahwa pencitraan (imaging) dan pemasaran daerah tujuan wisata harus memberikan banyak alternatif tentang tempat-tempat wisata bagi para wisatawan dan masyarakat.

Dengan demikian pariwisata ditinjau dari dimensi kultural dapat menumbuhkan suatu interaksi antara masyarakat tradisional agraris dengan masyarakat modern industrial. Melalui proses interaksi itu maka memungkinkan adanya suatu pola saling mempengaruhi yang pada akhirnya akan mempengaruhi struktur kehidupan atau pola budaya masyarakat khususnya masyarakat yang menjadi tuan rumah. Dari 
dimensi struktural budaya, aktivitas industri pariwisata memungkinkan terjadinya suatu perubahan pola budaya masyarakat yang diakibatkan oleh penerimaan masyarakat akan pola-pola kebudayaan luar yang dibawa oleh para pelancong. Pola-pola kebudayaan luar ini terekspresikan melalui tingkah laku, cara berpakaian, penggunaan bahasa serta pola konsumsi yang diadopsi dari wisatawan yang datang berkunjung.

Pemasaran wisata dengan pemilihan rute dan zonasi daerah tujuan wisata akan mengubah citra tempat. Pengadaan event-event kemasyarakatan dan penyelengggaraan hal-hal yang bersifat sejarah di tempat-tempat yang dikunjungi wisatawan juga mengubah kehidupan berbudaya dan bersejarah masyarakat, dan tentunya mengubah tempat itu sendiri. Pendapat Papson, seperti yang dikutip oleh Hall (1999) menyebutkan bahwa dari sekian banyak elemen penting dalam mengkomersiilkan suatu tempat untuk pariwisata adalah penyelenggaraan acara-acara kemasyarakatan dan pengelolaan sejarah menjadi komoditi yang dapat dipasarkan. Lebih lanjut dikatakan Papson dalam Hall (1999) bahwa sejarah yang semula merupakan sesuatu yang bersifat konseptual dan harus dialami, berubah menjadi sesuatu hal yang sensual dan dapat dinikmati dengan panca indera.

Berkenaan dengan hal tersebut memunculkan rambu-rambu untuk menekan dampak terhadap penurunan nilai-nilai budaya seperti dalam kode etik pariwisata dunia pasal 4 ayat 4 yang berbunyi "Kegiatan pariwisata harus direncanakan sedemikian rupa untuk memungkinkan kelangsungan hidup dan berkembangnya hasil-hasil budaya, seni tradisional, dan seni rakyat, dan bukan sebaliknya menimbulkan terjadinya standarisasi dan penurunan hasil-hasil budaya tersebut" (Anonim, $\mathrm{tt}$ ).

\section{Pariwisata Budaya Dalam Alternatif Pengenalan}

Sebagai hasil kecanggihan teknologi dan kemajuan komunikasi, pariwisata telah menjadi salah satu industri yang berkembang sangat cepat. Pariwisata global diharapkan terus berkembang karena orang mulai menemukan lebih banyak lagi daerah tujuan wisata dan industri perjalanan semakin lebih terorganisasi (Mowforth dan Maunt, 1998). Kemajuan teknologi informasi yang membawa dampak positif bagi kemajuan pariwisata budaya perlu 
disikapi dengan bijaksana, memanfaatkan kemajuan teknologi sesuai tren dan selera masyarakat untuk membujuk hati wisatawan maupun calon wisatawan. Pariwisata dan teknologi informasi adalah dua dari industriindustri terbesar dan yang paling dinamis di dunia saat ini. Secara terpisah dan bersama-sama kadua industri saat ini mampu merubah cara kerja masyarakat (Sheldon. 2001)

Sebagaimana mengutip tiga permasalahan pariwisata budaya pada bab II di atas, pada intinya masih adanya kesenjangan pemahaman wisatawan terhadap obyek yang mereka kunjungi, dan dampaknya karena kurangnya pemahaman terutama pemahan nilai-nilainya maka secara tidak sảar melanggar unsur-unsur pelestarian. Oleh karena itu perlu solusi yang tepat untuk "mencerdaskan" masyarakat wisatawan dan calon wisatawan menjadi "melk" atau terbuka wawasannya mengenai obyek budaya yang sedang dan akan mereka kunjungi. Solusi alternatif sesuai kemajuan teknologi informasi yang dapat ditawarkan antara lain:

1. Pembuatan film dokumenter ;

2. Pengenalan obyek wisata budaya melalui website;

3. Pembuatan CD interaktif;

4. Pembuatan program acara televisi;

5. Pembuatan program wap dalam seluler.

Ke lima tawaran di atas dapat menjangkau dari pengenalan dalam proses pencerdasan dan promosi untuk membuat orang tertarik untuk berkunjung. Teknis dalam pembuatan film dokumenter dimaksud adalah bentuk sajian produk informasi tentang nilai-nilai edukatif kultural pada obyek situs maupun atraksi-atraksi budaya. Isi kemasan ilmu dalam bentuk VCD/DVD yang akan disajikan dalam film dokumenter tersebut merupakan hasil penggalian atau penelitian-penelitian.

Pengenalan dalam bentuk film dokumenter, pembuatan website, dan pembuatan $C D$ interaktif mempunyai tujuan yang sama yaitu pengenalan, pendidikan, informasi dan promosi. Prosesnya dapat dilakukan sendiri oleh masing-masing pemangku kepentingan, kelompok masyarakat, dan birokrasi di pemerintahan. Namun bentuk-bentuk tersebut memiliki kelemahan yaitu hanya dari kalangan tertentu saja yang dapat menikmati atau mengakses karena adanya keterbatasan disribusi. Di lain pihak untuk 
pembuatan acara televisi dan pembuatan informasi dalam kemasan wap ke dalam telepon seluler dapat diakses lebih banyak orang, namun diperlukan kerjasama dengan pihak lain walaupun memerlukan waktu lama. Sedangkan pihak lain tersebut (stasiun televisi dan operator seluler) perlu diingat bahwa mereka mempunyai kepentingan lain yaitu orientasi bisnis. Oleh karena itu program yang ditawarkan seyogyanya secara teknis mendukung upaya yang saling menguntungkan kedua belah pihak.

Tawaran alternatif tersebut salah satu upaya menyampaikan paradigma "berpariwisata dengan cerdas". Diharapkan dari pariwisata cerdas adalah mampu membangun sikap memandang obyek wisata budaya dan bersikap berwisatanya itu sendiri sehingga mampu mereduksi dampak negatif. Sikap yang kritis terhadap dampak negatif pariwisata pada budaya dan pada lingkungan telah mendorong usaha yang kreatif untuk masuk dalam wacana sekarang ini, khususnya bagi mereka yang terpengaruh oleh adanya proses. Sifat perubahan sosial yang sangat kompleks dalam proses modernisasi, industrialisasi, dan pembangunan ekonomi yang mengikutinya harus menjadi konteks yang harus dipahami oleh pariwisata.

\section{Arah Kebijakan Program Pembangunan Kebudayaan dan Parivisata}

Indonesia yang dikenal dengan keanekaragaman budayanya (multikultur) masih dihadapkan pada persoalan-persoalan yang kompleks dan multidimensional. Sementara itu dampak globalisasi dan krisis ekonomi berperan timbulnya gejala lemahnya jatidiri bangsa dan gejala desintegrasi yang melanda di beberapa daerah. Oleh sebab itu peranan pemerintah di bidang pembangunan kebudayaan nasional menekankan bagaimana membangun karakter bangsa (nation and character building) dan bagaimana setiap warga negara diberi akses untuk saling mengenal kebudayaan yang berbeda agar dapat hidup berdampingan secara damai sebagaimana diamanatkan oleh para pendiri bangsa dan amanat mukadimah UUD 1945. Boleh dikatakan bahwa dewasa ini tidak ada satupun kebudayaan di dunia yang berkembang tanpa mengalami kontakkontak kebudayaan dan tukar menukar unsur-unsur kebudayaan, baik secara langsung maupun tidak langsung. Jumlah orang yang benar-benar genius dan mampu mengembangkan penemuan dan perekayasaan 
setempat biasanya terbatas. Karena itu perkembangan suatu kebudayaan yang mengandalkan pada penemuan dan perekayasaan setempat biasanya sangat lamban. Kebanyakan peradaban dunia dewasa ini, termasuk kebudayaan Eropa Barat yang melahirkan puncak-puncak peradaban dunia, merupakan hasil proses akulturasi.

Hampir secara universal pemerintah di seluruh dunia menerima pariwisata sebagai suatu yang baik, dengan sebagian besar kebijakan pariwisata dibuat untuk memperluas industri pariwisata. Pemerintah menempatkan pariwisata sebagai alat pembangunan dengan mempromosikan pariwisata sebagai cara mengatasi pengangguran di daerah yang secara ekonominya masih lemah. Sedangkan peranan pemerintah disamping sebagai regulator dalam pariwisata diantaranya berperan untuk koordinasi, perencanaan, perundang-undangan dan peraturan, dan stimulasi.

Dilematis pembangunan pariwisata dengan pembangunan kebudayaan diukur dari pengertian pariwisata dipresepsikan sebagai wahana untuk meningkatkan pendapatan, terutama pendapatan negara sebagai industri dan penghasil devisa dalam arti ekonomi-sentris dan berorientasi pertumbuhan sedangkan kebudayaan justru lebih bersifat konsumtif pengeluaran biaya. Apabila dipandang bagian per bagian maka antara kebudayaan dan pariwisata saling bertentangan namun dalam tujuan secara menyeluruh keduanya merupakan pisau bermata dua yang bermanfaat bagi pembangunan. Dalam hal ini juga sudah diatur dalam kode etik pariwisata dunia pasal 4 ayat 3 menyebutkan bahwa "sumber penghasilan yang diperoleh dari wisatawan ke tempat-tempat budaya dan monumen-monumen harus digunakan untuk setidak-tidaknya sebagian bagi pemeliharaan, pelestarian, pengembangan dan memperkaya warisan budaya" Lebih tegas Mowforth dan Maunt (1998) menyatakan bahwa pariwisata harus "dimanusiakan"', tidak hanya didorong oleh kekuatan pasar dan keuntungan semata-mata. Partisipasi masyarakat setempat dan upaya memasukkan budaya dan tradisi mereka dalam perencanaan akan menimbulkan respek/kebanggaan individu maupun masyarakat dari budaya tersebut.

Departemen Kebudayaan dan Pariwisata, dalam arah kebijakan program pembangunan salah satu unsurnya adalah penekanan Peningkatan 
peranserta dan pemberdayaan masyarakat serta UKM dalam perlindungan, pengembangan, dan pemanfaatan kebudayaan. Arah kebijakan pariwisata budaya tersebut kapasitas yang ditekankan hanya pada obyek atau industri wisatanya termasuk pelaku dan masyarakat yang berkaitan dengan lokasi obyek wisata bukan pada konsumen (wisatawannya).

Apabila selama ini program pembangunan birokrasi dilakukan atas orientasi nilai-nilai sentralistik dan efisiensi, maka di atas landasan paradigma pembangunan berwawasan budaya dilakukan dengan orientasi nilai humanisteranisme, demokrasi, dan partisipasi. Oleh karena itu dalam program dan kegiatan pembangunan kebudayaan pemerintah menggariskan kegiatan berupa revitalisasi dan reaktualisasi nilai-nilai tradisional yang bernilai luhur, dan transformasi kebudayaan untuk mengadopsi nilai-nilai baru yang positif untuk memperkaya dan memperkokoh khasanah budaya bangsa.

Sedangkan untuk karya budaya yang bersifat tangible dengan melakukan penyadaran dan pengenalan peninggalan-peninggalan budaya nenek moyang seperti candi, benteng, keraton, dan peninggalan kuna lainnya kepada masyarakat. Terutama kepada para siswa melalui kegiatan wisata pelajar dengan darma wisatanya atau dengan kemasan lain wisata sejarah dan lebih khusus dengan nama lawatan sejarah, dan dalam bentuk kemah budaya. Kegiatan ini difokuskan sebagai sasaran utamanya adalah generasi muda sebagai gegerasi penerus bangsa. Kegiatan ini bertujuan untuk menumbuhkan dan mengembangkan sikap memanfaatkan kebudayaan sebagaimana layaknya serta menumbuhkembangkan rasa cinta dan bangga terhadap hasil karya budaya bangsa. Dengan demikian arah pembangunan paeriwisata budaya selain mementingkan aspek ekonomi (devisa) adalah sangat perlu penekanan aspek pelestarian, yaitu pelestarian sumberdaya budaya sebagai asset pariwisata adalah sangat perlu untuk pelestarian asset nilai-nilai luhur bangsa melalui generasi penerus.

\section{Penutup}

Pariwisata sekarang ini bukan hanya sekedar pergerakan dari satu negara ke negara lain tetapi perpindahan komunitas massa yang mengikutinya, 
dan dampaknya pada masyarakat tradisional. Kenyataannya merupakan salah satu dari banyaknya dampak negatif. Dampak negatif ini disebabkan karena kurangnya perhatian yang diberikan pada persyaratan yang diperlukan bagi pariwisata yang berkesinambungan (Mowforth dan Maunt. 1998).

Pembangunan pariwisata budaya tanpa merusak hanya dapat dicapai dengan jika antara berbagai pihak seperti pemerintah, sektor swasta dan masyarakat bekerja bahu membahu untuk mencapai tujuan. Untuk membangun hubungan yang kuat maka perlindungan harus menjadi cara hidup atau gaya hidup, hal tersebut dari masyarakat dan kebudayaan nasional. Jika hubungan yang kuat tetap ada di skala lokal dan menyebarkan kebudayaan yang berorientasi pada negara, kemudian para turis juga didorong untuk memasuki garis untuk melihat dan menikmati namun tidak merusak karena telah mempunyai bekal pengetahuan tentang nilai-nilai luhurnya.

Bagaimana peranan pariwisata dalam pelestarian budaya maka kembali kepada pemerintah bersama masyarakat baik pemerintah pusat, propinsi, dan kabupaten/kota perlu memprogramkan sesuatu yang konkrit yang bertujuan upaya pelestarian aset budaya agar aset tersebut mengandung nilai-nilai positif sebagai sarana edukatif kultural, pariwisata dan pengembangan kebudayaan yang dapat berfungsi optimal untuk peningkatan pemahaman peradaban dan kesejahteraan masyarakat. Bentuk konkrit melalui penggunaan teknologi informasi (IT) sebagai sarana pengenalan, pendidikan, serta sarana promosi merupakan alternatif yang tepat untuk meninggalkan kesan kinerja manajeman "manual" serta "kuna' menuju "moderen" dan lebih cerdas.

Di era globalisasi, khususnya globalisasi informasi dimana jarak antar negara mejadi semakin menyempit dalam arti karena arus informasi antar negara di dunia semakin cepat dan terbuka, maka dapat berdampak terhadap budaya dari luar. Akar budaya bangsa yang digali berabad-abad dari bangsa sendiri yang memiliki nilai-nilai luhur budaya bangsa perlu dilestarikan, terutama budaya-budaya lokal yang berșifat non bendawi (intangible). 
Kekhawatiran banyak orang akan dampak negatif pengembangan pariwisata terhadap kelestarian kebudayaan dapat dimengerti karena banyak orang beranggapan bahwa suatu kebudayaan itu akan lestari kalau tidak tersentuh oleh pengaruh kebudayaan lain. Anggapan itu sama sekali tidak benar, oleh karena kebudayaan yang terisolir itu tetap akan mengalami perkembangan walaupun lamban. Pergantian generasi dan perubahan lingkungan akan merangsang penduduk untuk mengembangkan kebudayaan sesuai dengan kemampuan mereka menangkap dan memahami tantangan yang mereka hadapi. Dengan demikian, lambat atau cepat setiap kebudayaan akan mengalami perkembangan. Sedang pengaruh dari luar akan mempercepat perkembangan kebudayaan dengan melalui proses akulturasi.

\section{KEPUSTAKAAAN}

Anonim, tt. Pembangunan Berwawasan Budaya - Paradigma dan Pokok-pokok Program Aksi. Kementerian Kebudayaan dan Pariwisata - Universitas Gadjah Mada.

tt. Kode Etik Pariwisata Dunia (Global Code of Ethics For Tourism). Jakarta: Kementerian Kebudayaan dan Pariwisata RI. 2004. Profil Kementerian Kebudayaan dan Pariwisata Tahun 2004. Jakarta: Kementerian Kebudayaan dan Pariwisata RI.

, 2005. Rencana Strategis Departeman Kebudayaan dan

Pariwisata. Jakarta: Departeman Kebudayaan dan Pariwisata.

Hall, Colin Michael, 1999. Tourism and Pilitics: Policy Power and Place.

New York - Brisbane - Toronto - Singapore: John Wiley \& Sons.

Mowforth, M. and lan Mount. 1998. Tourism and Sustainability - New

Tourism in the Thirth World. London and New York.Routledge Publisher.

Sheldon. Pauline J. (ed.) 2001. Information and Communication Tecnology in Tourism 2001. Springer Verlag Wien. New York. Printed in Austria. 